\title{
PENGARUH KEPUASAN KERJA DAN KOMITMEN ORGANISASI TERHADAP ORGANIZATIONAL CITIZENSHIP BEHAVIOR PADA KARYAWAN HOTEL BERBINTANG DI BALI
}

\author{
Ni Luh Ketut Sri Sulistyawati \\ Program Studi Administrasi Perhotelan, Sekolah Tinggi Pariwisata Bali, nlk.sulistyawati@gmail.com
}

\begin{abstract}
ABSTRAK:
Organizational citizenship behavior (OCB) merupakan salah satu bentuk perilaku prososial yaitu perilaku sosial yang positif, konstruktif dan membantu. OCB ini tercermin melalui perilaku suka menolong orang lain, menjadi volunteer untuk tugastugas ekstra, patuh terhadap aturan-aturan dan prosedur-prosedur di tempat kerja. Perilaku tersebut akan muncul bila karyawan merasakan kepuasan dalam bekerja dan memiliki komitmen terhadap organisasi. Penelitian ini bertujuan untuk mengetahui pengaruh kepuasan kerja dan komitmen organisasi terhadap organizational citizenship behavior karyawan hotel berbintang di Bali secara parsial dan simultan. Data penelitian dikumpulkan melalui kuisioner dengan menggunakan 100 responden dan dianalisis dengan menggunakan amalisis regresi berganda. Hasil penelitian menunjukkan bahwa kepuasan kerja dan komitmen organisasi secara parsial maupun simultan berpengaruh positif dan signifikan terhadap organizational citizenship behavior karyawan. Berdasarkan uji determinasi ditemukan bahwa sumbangan variable kepuasan kerja dan komitmen organisasi sebesar 80,4 persen.
\end{abstract}

Kata kunci: Kepuasan kerja, komitmen organisasi, $O C B$

\section{ABSTRACT:}

Organizational citizenship behavior $(O C B)$ is one form of prosocial behavior that is positive social behavior, constructive and helpful. This $O C B$ is reflected through the behavior of helping others, volunteering for extra tasks, obeying the rules and procedures at work. Such behavior will arise when employees feel satisfaction in work and have a commitment to the organization. This study aims to determine the effect of job satisfaction and organizational commitment to the organizational citizenship behavior of star hotel employees in Bali partially and simultaneously. The research data was collected through questionnaire using 100 respondents and analyzed by using multiple regression analysis. The results showed that job satisfaction and organizational commitment partially or simultaneously have a positive and significant effect on organizational citizenship behavior of employees. Based on test of determination found that contribution of job satisfaction variable and organizational commitment equal to 80,4 percent.

Keywords: Job satisfaction, organizational commitment, $O C B$ 


\section{National Conference of Creative Industry: \\ Sustainable Tourism Industry for Economic Development}

Universitas Bunda Mulia, Jakarta, 5-6 September 2018

e-ISSN No: 2622-7436

\section{PENDAHULUAN}

Sumber daya manusia sebagai salah satu elemen utama dari perusahaan merupakan hal yang sangat penting karena faktor manusia sangat berperan dalam mencapai tujuan organisasi. Sumber daya manusia tidak saja membantu organisasi dalam mencapai tujuannya tetapi juga membantu menentukan apa yang benar-benar dapat dicapai dengan sumber daya yang tersedia. Pengelolaan SDM saat ini merupakan suatu keharusan dan bukan lagi merupakan suatu pilihan apabila perusahaan ingin berkembang. Perusahaan yang memiliki sumber daya manusia yang baik adalah sebagai modal agar dapat bersaing dengan perusahaan lain yang lebih maju. Kompetisi antar perusahaan semakin ketat, karena perusahaan tidak hanya dihadapkan pada persaingan dalam negeri, tetapi juga luar negeri. Menghadapi situasi dan kondisi tersebut, perusahaan harus menentukan strategi dan kebijakan manajemennya, khususnya dalam bidang Sumber Daya Manusia (SDM). Organisasi yang memiliki SDM yang baik akan menjadikan organisasi memiliki kekuatan untuk menghadapi persaingan (Cusway, 2002).

Salah satu sikap strategik dalam manajemen SDM organisasi adalah mengembangkan Organizational Citizenship Behavior (OCB). OCB ini tercermin melalui perilaku suka menolong orang lain, menjadi volunteer untuk tugas-tugas ekstra, patuh terhadap aturan-aturan dan prosedur-prosedur di tempat kerja (Robbins, 2008). Perilaku ini menggambarkan nilai tambah karyawan yang merupakan salah satu bentuk perilaku prososial, yaitu perilaku yang positif, konstruktif dan membantu. Oleh karena itu, kebutuhan dan keinginan dari karyawan sebagai SDM juga harus didukung oleh perusahaan agar karyawan dapat termotivasi untuk menunjukkan kinerja yang baik dan merasa puas atas hasil kerjanya. OCB saat ini memang belum begitu dikenal, namun pada dasarnya pegawai dalam suatu perusahaan atau organisasi kadang-kadang sudah menerapkan OCB pada waktu bekerja..

Robbins (2008) menyatakan kepuasan kerja mendorong munculnya OCB karena karyawan yang puas akan memiliki kemungkinan yang lebih besar untuk berbicara positif tentang organisasinya, membantu rekan kerja, dan menunjukkan kinerja yang melampaui perkiraan normal. Karyawan yang puas juga akan lebih patuh dalam melaksanakan tugas karena ingin mengulang pengalaman-pengalaman positif yang pernah dirasakan. Kepuasan kerja merupakan bentuk perasaan dan ekspresi seseorang ketika dia mampu/tidak mampu memenuhi harapan dari proses kerja dan kinerjanya. Kepuasan kerja yang dirasakan karyawan juga akan mendorong munculnya komitmen terhadap organisasi.

Luthans (2006) mengartikan komitmen organisasional sebagai sikap yang menunjukkan loyalitas karyawan dan merupakan proses yang berkelanjutan dalam mengekspresikan perhatiannya untuk kesuksesan organisasi. Komitmen adalah kemampuan dan kemauan untuk menyelaraskan perilaku pribadi dengan kebutuhan, prioritas dan tujuan organisasi. Hal ini mencakup cara-cara mengembangkan tujuan atau memenuhi kebutuhan organisasi yang intinya mendahulukan misi organisasi dari pada kepentingan pribadi. Dengan kata lain, komitmen organisasional adalah sesuatu yang menarik karena yang dilihat adalah sebuah keadaan psikologi karyawan untuk tetap bertahan dalam organisasi.

Organisasi yang sukses membutuhkan karyawan (SDM) yang akan bersedia melakukan ssuatu yang lebih dari sekedar tugas biasa dan juga akan menunjukkan kinerja yang melebihi harapan. Dalam dunia kerja yang dinamis seperti sekarang ini, 


\section{National Conference of Creative Industry: \\ Sustainable Tourism Industry for Economic Development}

Universitas Bunda Mulia, Jakarta, 5-6 September 2018 e-ISSN No: 2622-7436

tugas-tugas lebih sering harus dikerjakan dalam tim dan lebih mementingkan fleksibilitas. Hal tersebut tampak dalam perilaku seperti membantu individu lain dalam tim, memajukan diri untuk melakukan pekerjaan ekstra serta menghindari konflik yang tidak perlu. Kondisi yang sama juga berlaku di bidang perhotelan. Hotel merupakan suatu industri jasa yang sangat mengutamakan kepuasan bagi para tamu yang menginap. Hotel juga tergolong industri yang padat modal serta padat karya yang artinya pengelolaannya memerlukan modal usaha yang besar dan SDM yang banyak pula. Oleh karena itu sangat penting bagi hotel untuk benar-benar memperhatikan pengelolaan SDM yang dimiliki agar dapat menunjukkan kinerja yang diharapkan bahkan melampaui harapan tersebut.

Penelitian OCB sangat penting dilakukan di bidang hospitaliti karena sebagai perusahaan yang bergerak di bidang pelayanan maka faktor kepuasan tamu merupakan hal yang sangat penting. Ditengah persaingan yang semakin ketat, hotel juga dituntut memberikan pelayanan yang dapat memuaskan tamu /pelanggan sehingga karyawan dituntut untuk menunjukkan kinerja yang baik dan memberikan pelayanan yang berkualitas. Pada dasarnya seseorang dalam bekerja akan merasa nyaman pada perusahaan apabila memperoleh kepuasan kerja. Kinerja seseorang akan sangat dipengaruhi oleh tingkat kepuasan kerja yang dimiliki. Ketika karyawan merasa memperoleh kepuasan dalam bekerja maka karyawan tersebut akan bekerja secara maksimal untuk menyelesaikan pekerjaannya bahkan melakukan beberapa hal yang mungkin di luar tugasnya. Begitu juga ketika seseorang mempunyai komitmen yang tinggi terhadap organisasinya maka orang tersebut akan melakukan apapun untuk memajukan perusahaannya karena keyakinan terhadap organisasinya (Koesmono, 2005). Dengan kata lain kepuasan kerja dan komitmen karyawan akan mempengaruhi terbentuknya OCB. Penelitian Yesika Yuniar dkk (2011) menemukan bahwa kepuasan kerja dan komitmen berhubungan secara positif dan signifikan dengan OCB. Temuan ini diperkuat penelitian dari Darmawati dkk (2015) yang menemukan bahwa kepuasan kerja dan komitmen organisasi memiliki pengaruh yang positif dan signifikan terhadap OCB karyawan FISE UNY. Di sisi lain penelitian tentang OCB di industri perhotelan belum banyak dilakukan, sementara industri perhotelan sangat membutuhkan karyawan yang memiliki OCB yang tinggi. Oleh karena itu sangat penting untuk dilakukan kajian tentang pengaruh kepuasan kerja dan komitmen organisasi terhadap Organizational Citizenship Behaviour (OCB) karyawan hotel.. Penelitian ini bertujuan untuk mengetahui pengaruh kepuasan kerja dan komitmen organisasi terhadap Organizational Citizenship Behaviour (OCB) karyawan hotel berbintang di Bali

\section{TINJAUAN PUSTAKA}

\section{Organizational Citizenship Behavior}

Menurut Organ dalam Mohammad (2011), OCB didefinisikan sebagai pekerjaan yang berhubungan dengan perilaku yang tidak mengikat, tidak berkaitan dengan sistem reward formal organisasi, dan secara keseluruhan mampu meningkatkan efektivitas fungsi organisasi. Selain itu OCB dapat melampaui indikator kinerja yang dibutuhkan oleh sebuah organisasi serta mencerminkan tindakan-tindakan yang dilakukan oleh karyawan yang melampaui ketentuan minimum yang diharapkan oleh organisasi serta dapat meningkatkan kesejahteraan rekan kerja, kelompok kerja, dan perusahaan (Lovell, Kahn, Anton, Davidson, Dowling, et al, Mohammad 2011). 


\section{National Conference of Creative Industry: \\ Sustainable Tourism Industry for Economic Development}

Universitas Bunda Mulia, Jakarta, 5-6 September 2018

e-ISSN No: 2622-7436

\section{Dimensi OCB}

Terdapat dua dimensi perilaku karyawan yaitu general compliance (kepatuhan umum),dimana karyawan akan melakukan apa yang harus lakukan dan altruism yaitu bersedia membantu orang lain. Dalam perkembangannya konsep OCB mengalami beberapa perubahan. Diantaranya Dennis W. Organ dalam Mohammad (2011) di dalam penelitiannya mengungkapkan ada lima dimensi dalam OCB yaitu altruism, conscientiousness, sportsmanship, courtesy, dan civic virtue. Penelitian dari Organ ini merupakan salah satu penelitian yang dilakukan oleh para peneliti yang mempelajari dan menguji OCB pada pekerja dalam sebuah perusahaan. Dari beberapa penelitian tersebut ditemukan adanya hubungan positif antara OCB dengan aspek-aspek pekerjaan lainnya, seperti job satisfaction dan job characteristic. Karyawan yang sudah merasa puas dengan pekerjaannya mempunyai potensi yang lebih besar untuk menunjukkan OCB. Hal tersebut disebabkan oleh kepuasan dan rasa nyaman yang sudah diperoleh dalam menjalani pekerjaannya. Lima Dimensi dalam Organizational Citizenship Behavior meliputi :

Pertama, dimensi altruism yaitu tindakan suka rela yang dilakukan oleh seseorang atau pun kelompok orang untuk menolong orang lain tanpa mengharapkan imbalan apa pun, kecuali mungkin perasaan telah melakukan perbuatan baik (Sears dkk, Irfa 2012). Sedangkan menurut Walstern dan Piliavin dalam artikel Irfa (2012), perilaku altruistik ditunjukkan melalui perilaku menolong yang timbul bukan karena adanya tekanan atau kewajiban, melainkan bersifat suka rela dan tidak berdasarkan normanorma tertentu. Refleks menolong akan muncul apabila individu yang altruistif melihat seseorang yang perlu untuk dibantu, baik orang yang sudah dikenal maupun orang asing yang belum dikenal (stranger). Ciri-ciri lain dari perilaku ini adalah ketika seseorang melakukan tindakan altruisme pada beberapa orang, tindakan altruisme tersebut tidak berhubungan dengan tindakan altruismenya yang lain, karena individu yang altruistif tersebut memang tidak mengharapkan ada imbalan dari tindakannya tersebut di masa depan.

Kedua, dimensi conscientiousness mengacu pada sikap lebih berhati-hati dan mendengarkan kata hati. Big Five Teori memaparkan individu yang mempunyai skor tinggi pada traits conscientiousness memiliki kontrol diri yang bagus, terorganisir, memprioritaskan tugas, mengikuti norma dan peraturan.. Adanya perilaku tersebut dapat mengindikasikan bahwa para pekerja telah menerima dan mematuhi aturan dan prosedur yang ada di dalam perusahaan. Bila dilihat dari konteks sebuah perusahaan dengan adanya perilaku ini akan sangat menguntungkan, karena pekerja dengan conscientiousness yang tinggi akan memiliki sikap yang lebih baik daripada rekan-rekan kerjanya yang lain yaitu ditunjukkan dengan ketaatan pada regulasi dan prosedur perusahaan yang lebih baik.

Ketiga, dimensi courtesy digambarkan dengan sebuah bentuk tindakan yang bertujuan untuk mencegah munculnya masalah,. Secara arti kata courtesy dapat diartikan dengan sikap sopan dan mempertimbangkan orang lain. Contoh tindakan Courtesy dalam dunia kerja antara lain menawari teman kerja untuk makan bersama, apabila sedang memiliki tugas yang sama selalu mengingatkan teman kerjanya agar tidak lupa atau mungkin menawarinya untuk saling sharing dan bertukar pikiran menyelesaikan tugas tersebut.

Keempat, dimensi Sportsmanship yang dapat dilihat dari aspek toleransi dan keluhan (complain) individu dalam melakukan pekerjaannya. Individu dengan sikap sportsmanship yang tinggi akan sangat memperhatikan hal-hal detail dalam 


\section{National Conference of Creative Industry: \\ Sustainable Tourism Industry for Economic Development}

Universitas Bunda Mulia, Jakarta, 5-6 September 2018 e-ISSN No: 2622-7436

pekerjaannya, melakukan pekerjaan dengan fair dan tidak banyak mengeluh serta memiliki kemampuan beradaptasi yang tinggi. Dalam konteks sebuah perusahaan sikap ini tentunya akan sangat menguntungkan karena para pekerja akan dengan mudah beradaptasi dengan perubahan yang terjadi di perusahaan. Hal tersebut terlihat bila perusahaan mengeluarkan kebijakan baru mengenai suatu hal, pekerja yang memiliki sikap sportsmanship tinggi akan dengan mudah menerima kebijakan baru itu dan mengesampingkan masalah-masalah kecil yang mungkin akan muncul.

Kelima, dimensi Civic virtue ditunjukkan dengan perilaku turut serta secara penuh (self involvement) dan lebih perhatian terhadap perusahaan. Individu dengan civic virtue yang tinggi akan sangat memperhatikan kepentingan perusahaannya. Hal tersebut dapat ditunjukkan dengan selalu berperan aktif dalam semua kegiatan yang ada dalam perusahaan, seperti training pegawai, workshop, dan lain sebagainya. Selain itu juga selalu memperhatikan informasi penting baik dari luar ataupun dari dalam perusahaan yang dapat bermanfaat bagi perusahaannya.

\section{Kepuasan Kerja}

Kepuasan kerja merupakan salah satu faktor penting yang mempengaruhi kepuasan hidup karena sebagian besar waktu manusia dihabiskan di tempat kerja. Menurut Setiawan dan Ghozali (2016:159) kepuasan kerja merupakan kondisi menyenangkan atau secara emosional positif yang berasal dari penilaian seseorang atas pekerjaannya atau pengalaman kerjanya. Sedangkan menurut Handoko (2001:193) kepuasan kerja merupakan keadaan emosional bagaimana seorang karyawan memandang pekerjaannya apakah menyenangkan atau tidak menyenangkan. Dengan kata lain dapat dikatakan bahwa kepuasan kerja mencerminkan persaan seseorang terhadap pekerjaannya.

\section{Faktor Yang mempengaruhi Kepuasan Kerja}

Lima faktor yang mempengaruhi kepuasan kerja yaitu (1) pemenuhan kebutuhan dimana kepuasan ditentukan oleh tingkatan karakteristik pekerjaan yang memberikan kesempatan pada individu untuk memenuhi kebutuhannya; (2) perbedaan yaitu perbedaan antara apa yang diharapkan dan yang diperoleh individu dari pekerjaan; (3) pencapaian nilai, bahwa kepuasan adalah merupakan hasil dari persepsi pekerjaan yang memberikan pemenuhan kebutuhan nilai kerja individual yang penting; (4) keadilan, bahwa kepuasan merupakan fungsi dari seberapa adil individu diperlakukan di tempat kerja; (5) komponen genetik yang menyatakan bahwa kepuasan kerja sebagian merupakan fungsi sifat pribadi dan faktor genetic ( Kreitner dan Kinicki dalam Wibowo, 2011:504).

Faktor yang mempengaruhi kepuasan kerja menurut Robins (2002:45) meliputi (1) pekerjaan itu sendiri yaitu pandangan karyawan mengenai pekerjaannya sebagai sesuatu yang menarik dan melalui pekerjaan tersebut karyawan memperoleh kesempatan untuk belajar; (2) pengawasan yaitu usaha mempengaruhi kegiatan bawahan melalui proses komunikasi untuk mencapai tujuan tertentu yang ditetapkan organisasi; (3) imbalan yaitu bila imbalan dipersepsikan adil yang didasarkan pada tuntutan pekerjaan, tingkat keterampilan individu dan standar pengupahan komunitas maka kemungkinan besar akan menimbulkan kepuasan; (4) kesempatan promosi memberikan pengaruh yang berbeda terhadap kepuasan kerja karena adanya perbedaan balas jasa yang diberikan. Promosi akan selalu diikuti oleh tugas, tanggung jawab dan wewenang lebih tinggi sehingga perusahaan akan memperoleh kestabilan dan moral 


\section{National Conference of Creative Industry: \\ Sustainable Tourism Industry for Economic Development}

Universitas Bunda Mulia, Jakarta, 5-6 September 2018 e-ISSN No: 2622-7436

karyawan lebih terjamin; (5) rekan kerja yang bersahabat, kerjasama rekan sekerja adalah sumber kepuasan kerja bagi pekerja secara individual sedangkan kelompok kerja dapat memberikan dukungan, nasehat atau saran kepada sesama rekan kerja.

\section{Komitmen Organisasi}

Dalam perilaku organisasi, terdapat beragam definisi tentang komitmen. Sebagai suatu sikap, menurut Luthans (1992) yang menyatakan komitmen organisasi merupakan keinginan yang kuat untuk menjadi anggota dalam suatu kelompok, kemauan usaha yang tinggi untuk organisasi, dan suatu keyakinan tertentu dan penerimaan terhadap nilai-nilai dan tujuan-tujuan organisasi. Dengan kata lain, komitmen organisasi merupakan sikap yang merefleksikan loyalitas karyawan pada organisasi dan proses berkelanjutan di mana anggota organisasi mengekspresikan perhatiannya terhadap organisasi dan keberhasilan serta kemajuan yang berkelanjutan.

Mathins dan Jackson (2000) memberikan definisi Komitmen Organisasi sebagai derajat yang mana karyawan percaya dan menerima tujuan-tujuan organisasi dan akan tetap tinggal atau tidak akan meninggalkan organisasi. Sedangkan menurut Mowday (dalam Fadjrianthi, 2012:105) komitmen organisasi merupakan keinginan untuk tetap menjadi anggota organisasi, kepercayaan dan penerimaan akan nilai-nilai dan tujuan organisasi, serta kesediaan untuk berusaha sebaik mungkin demi kepentingan organisasi. Komitmen organisasi menekankan derajat keberpihakan identitas diri personil pada tujuan organisasi tertentu dalam hasrat untuk memelihara keanggotaannya pada organisasi (Robbins, 2001).

\section{Komponen Komitmen Organisasi}

Mayer dan Allen (1990) menyatakan bahwa komitmen organisasi merefleksikan tiga komponen umum yaitu Pertama, Komitmen sebagai keterikatan afektif pada organisasi (affective commitment) adalah tingkat keterikatan secara psikologis dengan organisasi berdasarkan seberapa baik perasaan mengenai organisasi. Komitmen jenis ini muncul dan berkembang oleh dorongan adanya kenyamanan, keamanan, dan manfaat lain yang dirasakan dalam suatu organisasi yang tidak diperolehnya dari tempat atau organisasi yang lain. Semakin nyaman dan tinggi manfaat yang dirasakan oleh anggota maka semakin tinggi komitmen seseorang pada organisasi. Kedua, Komitmen sebagai biaya yang harus ditanggung jika meninggalkan atau keluar organisasi (continuance commitment) yang didefinisikan sebagai keterikatan anggota secara psikologis pada organisasi karena biaya yang dia tanggung sebagai konsekuensi keluar organisasi. Dalam kaitannya dengan hal ini anggota akan mengkalkulasi manfaat dan pengorbanan atas keterlibatan menjadi anggota suatu organisasi. Anggota akan cenderung memiliki daya tahan atau komitmen yang tinggi dalam keanggotaan jika pengorbanan akibat keluar organisasi semakin tinggi. Ketiga, Komitmen sebagai kewajiban untuk tetap dalam organisasi (normative commitment) adalah keterikatan anggota secara psikologis dengan organisasi karena kewajiban moral untuk memelihara hubungan dengan organisasi. Berkaitan dengan ini sesuatu yang mendorong anggota untuk tetap berada dan memberikan sumbangan pada keberadaan suatu organisasi, baik materi maupun non materi adalah adanya kewajiban moral yang mana seseorang akan merasa tidak nyaman dan bersalah jika tidak melakukan sesuatu.

Kanter (1986) mengemukakan adanya 3 bentuk komitmen organisasional, yaitu pertama, komitmen berkesinambungan (continuance commitment) yaitu komitmen yang berhubungan dengan dedikasi anggota dalam melangsungkan kehidupan 


\section{National Conference of Creative Industry: \\ Sustainable Tourism Industry for Economic Development}

Universitas Bunda Mulia, Jakarta, 5-6 September 2018 e-ISSN No: 2622-7436

organisasi dan menghasilkan orang yang mau berkorban dan berinvestasi pada organisasi. Kedua, komitmen terpadu (cohesion commitment), yaitu komitmen anggota terhadap organisasi sebagai akibat adanya hubungan sosial dengan anggota lain di dalam organisasi. Ini terjadi karena karyawan percaya bahwa norma-norma yang dianut organisasi merupakan norma-norma yang bermanfaat. Ketiga, komitmen terkontrol (control commitment) yaitu komitmen anggota terhadap norma organisasi yang memberikan perilaku ke arah yang diinginkannya. Norma-norma yang dimiliki organisasi sesuai dan mampu memberikan sumbangan terhadap perilaku yang diinginkannya.

\section{Faktor yang Mempengaruhi Komitmen Organisasi}

Menurut Allen \& Meyer (1997) faktor-faktor yang mempengaruhi komitmen organisasi meliputi : pertama, karakteristik pribadi individu yaitu terbagi ke dalam dua variabel, yaitu variabel demografis dan variabel disposisional. Variabel demografis mencakup gender, usia, status pernikahan, tingkat pendidikan, dan lamanya seseorang bekerja pada suatu organisasi. Sedangkan variabel disposisional mencakup kepribadian dan nilai yang dimiliki anggota organisasi, kebutuhan untuk berprestasi dan etos kerja yang baik, kebutuhan untuk berafiliasi dan persepsi individu mengenai kompetensinya sendiri. Kedua, karakteristik organisasi adalah struktur organisasi, desain kebijaksanaan dalam organisasi, dan bagaimana kebijaksanaan organisasi tersebut disosialisasikan. Ketiga, pengalaman selama berorganisasi tercakup ke dalam kepuasan dan motivasi anggota organisasi selama berada dalam organisasi, perannya dalam organisasi tersebut serta hubungan antara anggota organisasi dengan supervisor atau pemimpinnya (Allen \& Meyer, 1997).

Steers dalam Sopiah (2008) mengidentifikasi tiga faktor yang mempengaruhi komitmen karyawan pada organisasi, yaitu: (1) ciri pribadi pekerja, termasuk masa jabatannya dalam organisasi, variasi, kebutuhan dan keinginan yang berbeda dari tiap karyawan; (2) ciri pekerjaan, seperti identitas tugas dan kesempatan berinteraksi dengan rekan sekerja; (3) pengalaman kerja, seperti keterandalan organisasi di masa lampau dan cara pekerja-pekerja lain mengutarakan dan membicarakan perasaannya mengenai organisasi. Sedangkan David (dalam Minner, 1997) mengemukakan empat faktor yang mengaruhi komitmen karyawan pada organisasi, yaitu: (1) Faktor personal, misalnya usia, jenis kelamin, tingkat pendidikan, pengalaman kerja, kepribadian; (2) Karakteristik pekerjaan, misalnya lingkup jabatan, tantangan dalam pekerjaan, konflik peran dalam pekerjaan dan tingkat kesulitan dalam pekerjaan; (3) Karakteristik struktur, misalnya besar/kecilnya organisasi, bentuk organisasi seperti sentralisasi atau desentralisasi, kehadiran serikat pekerja dan tingkat pengendalian yang dilakukan organisasi terhadap karyawan; (4) Pengalaman kerja sangat berpengaruh terhadap tingkat komitmen karyawan pada organisasi. Karyawan yang baru beberapa tahun bekerja dan karyawan yang sudah puluhan tahun bekerja dalam organisasi tentu memiliki tingkat komitmen yang berlainan.

\section{METODE PENELITIAN}

Populasi dalam penelitian ini adalah karyawan yang bekerja pada hotel berbintang di Bali. Teknik pengambilan sampel yang digunakan dalam penelitian ini adalah non probability sampling yaitu teknik sampling yang tidak memberi peluang atau kesempatan yang sama bagi setiap unsur atau anggota populasi untuk dipilih menjadi anggota sampel, dengan menggunakan purposive sampling yaitu teknik 


\section{National Conference of Creative Industry: \\ Sustainable Tourism Industry for Economic Development}

Universitas Bunda Mulia, Jakarta, 5-6 September 2018

e-ISSN No: 2622-7436

penentuan sampel dengan maksud dan tujuan tertentu (Sugiyono, 2010). Kriteria sampel yang digunakan adalah karyawan tetap yang sudah bekerja selama minimal 2 tahun. Jumlah sampel yang akan diteliti adalah 100 karyawan.

Data dikumpulkan dengan metode kuesioner yaitu dengan memberikan daftar pertanyaan atau kuesioner secara langsung kepada para responden. Kuesioner yang akan dibagikan terdiri atas dua bagian yaitu profil responden dan dan faktor-faktor yang mempengaruhi Organizational Citizenship Behaviour (OCB) yaitu Kepuasan Kerja dan Komitmen Organisasi. Kuesioner yang dibagikan tersebut merupakan kuesioner yang bersifat tertutup dengan menggunakan skala Likert dimana jawaban responden telah dibatasi dengan menyediakan alternatif jawaban. Berdasarkan skala Likert maka jawaban responden terhadap pernyataan yang terdapat pada kuesioner $\mathrm{COB}$ dan komitmen organisasi diberi nilai sebagai berikut : $1=$ sangat tidak setuju; $2=$ tidak setuju ; 3 = Netral; 4 = Setuju; 5 = sangat setuju. Sedangkan jawaban responden terhadap pernyataan pada kuesioner kepuasan kerja diberi nilai sebagai berikut : $1=$ sangat tidak puas; $2=$ tidak puas; $3=$ netral; $4=$ puas; $5=$ sangat tidak puas.

\section{HIPOTESIS}

Berdasarkan metode penelitian yang telah dijabarkan diatas, maka hipotesis dalam penelitian ini adalah :

H1 : Kepuasan kerja dan komitmen Organisasi secara simultan berpengaruh positif dan signifikan terhadap Organizational Citizenship Behavior (OCB) pada karyawan hotel berbintang di Bali.

H2 : Kepuasan kerja karyawan secara parsial berpengaruh positif dan signifikan terhadap Organizational Citizenship Behavior (OCB) pada karyawan hotel berbintang di Bali.

H3 : Komitmen Organisasi secara parsial berpengaruh positif dan signifikan terhadap Organizational Citizenship Behavior (OCB) pada karyawan hotel berbintang di Bali.

\section{Hasil dan Pembahasan}

Pengaruh variabel kepuasan kerja dan komitmen organisasional terhadap organizational citizenship behavior karyawan hotel berbintang secara simultan dapat diketahui melalui uji $\mathrm{F}$. Pengaruh simultan kedua variabel dapat dilihat dari nilai signifikansi hasil uji Anova pada Tabel 3.

Tabel 3 Hasil Pengujian Variabel Kepuasan Kerja dan Komitmen Organisasional terhadap Organizational Citizenship Behavior (OCB)

\begin{tabular}{|l|r|r|r|r|r|}
\hline Model & Sum of Squares & df & Mean Square & \multicolumn{1}{c|}{ F } & Sig. \\
\hline 1 Regression & 13012,391 & 2 & 6506,196 & 204,485 &, $000^{\text {D }}$ \\
Residual & 3086,291 & 97 & 31,817 & & \\
Total & 16098,683 & 99 & & & \\
\hline
\end{tabular}
a. Dependent Variable: Y
a. Predictors: (Constant), X2, X1
Sumber : Hasil pengolahan data (2017)

Tabel 3 menunjukkan bahwa nilai signifikansi sebesar 0,000 yang berarti bahwa variable kepuasan kerja (X1) dan komitmen organisasi (X2) secara simultan 
berpengaruh terhadap organizational citizenship behavior (OCB) karyawan hotel berbintang di Bali berarti bahwa Hipotesis 1 (H1) diterima.

Analisis Determinasi dalam regresi linier berganda digunakan untuk mengetahui persentase sumbangan pengaruh variabel independen terhadap variabel dependen.

\section{Tabel 2 Koefisien Determinasi}

Model Summary

\begin{tabular}{l|l|l|l|l|}
\hline Model & $\mathrm{R}$ & $\mathrm{R}$ Square & $\begin{array}{l}\text { Adjusted } \\
\text { Square }\end{array}$ & $\begin{array}{l}\text { Std. Error of the } \\
\text { Estimate }\end{array}$ \\
\hline 1 &, $899^{\mathrm{a}}$ &, 808 &, 804 & 5,64069 \\
\hline
\end{tabular}
a. Predictors: (Constant), $\mathrm{X} 2, \mathrm{X} 1$
a. Dependent Variable: $\mathrm{Y}$

Berdasar Tabel 2 dapat diketahui nilai $\mathrm{R}^{2}$ sebesar 0,804. Dapat diartikan bahwa Kepuasan kerja $\left(\mathrm{X}_{1}\right)$ dan Komitmen organisasi $\left(\mathrm{X}_{2}\right)$ mempengaruhi organizational citizenship behavior (Y) sebesar 80,4\%. Hasil tersebut menunjukkan bahwa kepuasan kerja dan komitmen organisasional memiliki pengaruh yang dominan terhadap terbentuknya perilaku kewargaan organisasi (organizational citizenship behavior) karyawan hotel berbintang di Bali.

Uji t dilakukan untuk mengetahui seberapa besar pengaruh variabel kepuasan kerja (X1) dan Komitmen Organisasional (X2) terhadap OCB (Y) karyawan hotel berbintang di Bali dilihat dari nilai signifikansinya. Apabila nilai signifikansi lebih kecil dari 0,05 berarti variabel tersebut berpengaruh positif dan signifikan. Berdasarkan Tabel 1 maka hasil pengujian hipotesis (H2) dan $\mathrm{H} 3$ dijabarkan sebagai berikut :

\section{Tabel 1 Hasil Pengujian Variabel Kepuasan Kerja (X1) dan Komitmen Organisasi (X2) terhadap Organizational Citizenship Behavior (Y)}

Coefficients $^{\mathrm{a}}$

\begin{tabular}{|ll|r|r|r|r|r|}
\hline \multirow{2}{*}{ Model } & \multicolumn{2}{|c|}{ Unstandardized Coefficients } & Standardized Coefficients & & \\
\cline { 3 - 8 } & (Constant) & B & Std. Error & Beta & t & \multicolumn{2}{c|}{ Sig. } \\
\hline 1 & 2,122 & 2,138 &, 993 &, 323 \\
& X1 &, 321 &, 059 &, 337 & 5,435 &, 000 \\
\cline { 2 - 8 } & X2 &, 829 &, 081 &, 631 & 10,172 &, 000 \\
\hline
\end{tabular}

a. Dependent Variable: $Y$

Sumber : Hasil olah data (2017)

a) Pengujian $\mathrm{H} 2$

Nilai signifikansi variabel Kepuasan kerja (X1) terhadap terhadap OCB adalah 0,000 berarti bahwa variabel kepuasan kerja secara parsial berpengaruh positif dan signifikan terhadap Organizational Citizenship Behavior (OCB) karyawan.

b) Pengujian $\mathrm{H} 3$

Nilai signifikansi variabel komitmen organisasi (X2) terhadap Organizational Citizenship Behavior sebesar 0,000 yang berarti bahwa variabel komitmen 


\section{National Conference of Creative Industry: \\ Sustainable Tourism Industry for Economic Development}

Universitas Bunda Mulia, Jakarta, 5-6 September 2018 e-ISSN No: 2622-7436

organisasi (X2) secara parsial berpengaruh positif dan signifikan terhadap Organizational Citizenship Behavior.

Berdasarkan hasil pengujian hipotesis degan uji t ditemukan adanya pengaruh positif dan signifikan antara kepuasan kerja dengan OCB. Hasil ini memiliki arti jika semakin tinggi tingkat kepuasan kerja yang dirasakan oleh karyawan meliputi perasaan puas terhadap pekerjaan itu sendiri, pengawasan, program pengembangan SDM serta rekan kerja yang bersahabat maka OCB akan meningkat. Karyawan yang puas akan lebih besar untuk berbicara secara positif tentang organisasi, membantu rekan kerja, dan membuat kinerja pekerjaan mereka melampaui perkiraan normal, lebih dari itu karyawan yang puas lebih patuh terhadap panggilan tugas (Robbins, 2006). Temuan ini sesuai dengan hasil penelitian Puput Wulandari (2013) yang menunjukkan hasil bahwa kepuasan kerja berpengaruh terhadap organizational citizenship behavior (OCB).

Pengujian hipotesis untuk variable komitmen organisasi juga menemukan adanya pengaruh positif dan signifikan antara komitmen organisasi dengan OCB. Hasil ini memiliki arti jika semakin tinggi komitmen organisasi yang dimiliki oleh karyawan seperti memiliki rasa kekeluargaan terhadap perusahaan, merasa rugi jika meninggalkan perusahaan serta memiliki komitmen terhadap perusahaan maka perilaku OCB yang dimiliki karyawan juga akan meningkat. Komitmen organisasi meliputi komitmen afektif atau keterikatan afektif pada organisasi, keterikatan anggota secara psikologis pada organisasi (continuance commitment), dan komitmen sebagai kewajiban untuk tetap dalam organisasi (normatif commitment) (Mayer dan Allen dalam Fadjrianthi, 2012: 105).

Pengaruh variabel kepuasan kerja dan komitmen organisasional terhadap organizational citizenship behavior karyawan hotel berbintang secara simultan dapat diketahui melalui uji F. Pengaruh simultan kedua variabel dapat dilihat dari nilai signifikansi hasil uji Anova yang kurang dari 0,05 (taraf nyata 5\%). pengaruh variabel independen kepuasan kerja $\left(\mathrm{X}_{1}\right)$ dan komitmen organisasi $\left(\mathrm{X}_{2}\right)$ secara simultan terhadap variabel dependen organizational citizenship behavior (Y). Kepuasan kerja $\left(\mathrm{X}_{1}\right)$ dan Komitmen organisasi $\left(\mathrm{X}_{2}\right)$ mempengaruhi organizational citizenship behavior (Y) sebesar 80,4\%. Hasil tersebut menunjukkan bahwa kepuasan kerja dan komitmen organisasional memiliki pengaruh yang dominan terhadap terbentuknya perilaku kewargaan organisasi (organizational citizenship behavior) karyawan hotel berbintang di Bali. Perilaku tersebut diantaranya akan muncul dalam tindakan sukarela menolong orang lain, memiliki kontrol diri yang bagus, sikap sopan dan mempertimbangkan orang lain, mampu beradaptasi dengan situasi dan perubahan lingkungan kerjanya serta loyal dan selalu berperan aktif dalam semua kegiatan yang ada dalam perusahaan.

Penelitian yang dilakukan oleh Arum Daruwati dkk (2011) juga mengungkapkan hal yang sama bahwa kepuasan kerja dan komitmen organisasional berpengaruh positif dan signifikan terhadap OCB. Bukti lain yang menyatakan bahwa kepuasan kerja berhubungan erat atau berpengaruh terhadap OCB adalah penelitian Maranaka (2012) tentang pengaruh kepuasan kerja dan komitmen organisasi terhadap OCB dan Yanti Astika Dewi, dkk (2016) yang menemukan bahwa kepuasan kerja dan komitmen organisasi berpengaruh positif dan signifikan terhadap OCB.

\section{KESIMPULAN DAN IMPLIKASI}

Berdasarkan analisis dan pembahasan yang dilakukan dalam penelitian ini, maka simpulan yang dihasilkan adalah sebagai berikut: (1) Variabel kepuasan kerja dan 


\section{National Conference of Creative Industry: \\ Sustainable Tourism Industry for Economic Development}

Universitas Bunda Mulia, Jakarta, 5-6 September 2018 e-ISSN No: 2622-7436

komitmen organisasional secara simultan berpengaruh positif dan signifikan terhadap organizational citizenship behavior karyawan hotel berbintang di Bali. Hal ini dapat dilihat dari hasil analisis regresi berganda, analisis uji $\mathrm{F}$ yang menunjukkan nilai signifikansi lebih kecil dari 0,05; (4) Analisis determinasi $\left(\mathrm{R}^{2}\right)$ menunjukkan bahwa variabel kepuasan kerja dan komitmen organisasional secara simultan berkontribusi sebesar 80,4\% terhadap organizational citizenship behavior karyawan hotel berbintang di Bali; (2) Secara parsial variabel kepuasan kerja berpengaruh positif dan signifikan terhadap organizational citizenship behavior karyawan hotel berbintang di Bali sesuai hasil pengujian dengan analisis uji t, yang menunjukkan nilai signifikansi yang lebih kecil dari 0,05; (3) Secara parsial komitmen organisasional berpengaruh positif dan signifikan terhadap organizational citizenship behavior karyawan hotel berbintang di Bali sesuai hasil pengujian dengan analisis uji t yang menunjukkan nilai signifikansi yang lebih kecil dari 0,05;

Berdasarkan simpulan yang telah disebutkan, diajukan beberapa saran sebagai berikut: (1) Melihat pengaruh variabel kepuasan kerja dan komitmen organisasional yang signifikan dan dominan $(80,4 \%)$ terhadap organizational citizenship behavior, maka hendaknya manajemen hotel lebih fokus untuk mempertahankan dan bahkan meningkatkan aspek kepuasan kerja dan komitmen organisasional karyawannya untuk meningkatkan aspek organizational citizenship behavior; (2). Usaha-usaha yang dapat dilakukan untuk meningkatkan kepuasan kerja di antaranya: (a) memberikan kesempatan karyawan untuk mengembangkan diri sehingga memiliki peluang yang lebih baik dalam peningkatan karier; (b) menjaga hubungan yang baik antara rekan sekerja sehingga dapat memberikan rasa nyaman dalam bekerja; (c) Atasan yang semakin memperhatikan bawahannya dengan memberikan semangat, dorongan, dan motivasi yang lebih, akan menambah kepuasan kerja yang terus tercapai, sehingga karyawan menjadi lebih berkomitmen dengan rasa tanggung jawab secara sukarela terhadap pekerjaannya yang timbul dari dalam diri masing-masing karyawan; (3) dalam meningkatkan komitmen organisasional, perlu menciptakan hubungan yang baik serta memberikan suasana kerja yang lebih kondusif, kekeluargaan dan adanya keterbukaan pimpinan perusahaan. Hal ini akan dapat lebih memudahkan komunikasi di antara para karyawan, sehingga komitmen kerja bisa lebih meningkat.

\section{DAFTAR PUSTAKA}

Andriani, G., Djalali, A.M., \& Sofiah, D. 2012. Organizational Citizenship Behaviordan Kepuasan Kerja Pada Karyawan. Jurnal Penelitian Psikologi, 3(1), 341-154.

Bolon, Douglas S, 1997. Organizational citizenship behavior among hospital employees: A multidimensional Analysis Involving Job Satisfaction and Organization Commitment, Hospital \& Health Services Administration; Summer 1997; 42, 2; ABI/INFORM Research pg. 221

Darmawati, Hidayati, dan Herlina. 2013. Pengaruh Kepuasan kerja, Komitmen Organisasi terhadap Organizational Citizenship Behavior. Jurnal Economia 9,1: 10-17.

Kurniawan, Albert. 2015. Pengaruh Komitmen Organisasi terhadap Organizational Citizenship Behavior (OCB) PT X Bandung. Jurnal Manajemen 15, 1: 95-118. 


\section{National Conference of Creative Industry: \\ Sustainable Tourism Industry for Economic Development}

Universitas Bunda Mulia, Jakarta, 5-6 September 2018 e-ISSN No: 2622-7436

Luthans, Fred. 2006. Perilaku organisasi, Edisi sepuluh, Penerbit ANDI Yogyakarta

Mohamed, M Sheik, dan H Anisa. 2012. Relationship Between Organizational Commitment and Organizational Citizenship Behavior. IUP Journal of Organizational Behavior XI, 3: 7-22.

Muranaka, Andi Shigemi.2012. Pengaruh Kepuasan Kerja dan Komitmen Organisasi terhadap OCB pada karyawan BPR Dana Niaga Mandiri Makassar. Skrpsi tidak diterbitkan. Makassar: Fakultas Ekonomi dan Bisnis Universitas Hassanudin.

Purba, Debora Eflina dan Ali Nina Liche Seniati. 2004. Pengaruh Kepribadian dan Komitmen Organisasi terhadap Organizational Citizenship Behavior. Makara, Sosial Humaniora 8, 3: 105-111

Ribke Widyanto, Jennie Suhandono Lau, Endo Wijaya Kartika. 2013. Pengaruh Kepuasan Kerja terhadap Organizational Citizenship Behavior (OCB) melalui Komitmen Organisasional karyawan Cleaning Service di ISS Surabaya . (http://studentjournal.petra.ac.id/index.php/manajemen-perhotelan/article/view/199, diakses 14 Pebruari 2017).

Robbins dan Judge .2008.Perilaku Organisasi Buku 1 cetakan 12. Jakrta: Salemba Empat

Sambung, Robby. 2011. Pengaruh Kepuasan Kerja terhadap OCB-I dan OCB-O dengan dukungan organisasi sebagai variabel moderating (Studi pada Universitas Palangkaraya). Analisis Manajemen Vol. 5 No. 2 Desember 2011 (online)

(https://www.google.co.id/search?q=+Pengaruh++Kepuasan+Kerja+terhadap $+\mathrm{O}$ CB-I+dan+OCB-

O+dengan+dukungan+organisasi+sebagai+variabel+moderating+(Studi+pada++ Universitas+Palangkaraya).+Analisis+Manajemen+Vol.+5+No.+2+Desember +2 $\underline{011 \& h l=i d \& a u t h u s e r=0)}$ diakses 12 Desember 2016

Saputra, Andrew Adi, Liemdra hendro Yono, dan Laksmi Sito Dwi Irvianti. 2013. Analisis Pengaruh Keterlibatan Kerja dan Kepuasan Kerja Terhadap Organizational Citizenship Behavior di PT Prima Graphia Digital. Binus Business Riview 4, 2: 897-903.

Shore, L., Wayne, S.J. 1993. Commitment and employee behavior: comparison of affective commitment and continuance commitment with perceived organizational support, Journal of Applied Psychology, Vol. 78 No.5, pp.774-80

Simamora, Henry.2004. Manajemen Sumber Daya Manusia Edisi ketiga. Yogyakarta: Sekolah Tinggi Ilmu Ekonomi YKPN

Sopiah. 2008 Perilaku Organisasional. Yogyakarta: Penerbit Andi.

Sugiyono. 2011. Metode Penelitian Kuantitatif, Kualitatif, dan R\&D. Bandung: AFABETA, CV. 
Wahyuningsih. 2009. Pengaruh Komitmen Organisasi terhadap Organizational Citizenship Behavior Karyawan Rumah Sakit PKU Muhammadiyah. Jurnal Ilmu Pendidikan, (Online), (http://staff.uny.ac.id/sites/default/files/penelitian/Arum\%20Darmawati,\%20SE., MM./Pengaruh\%20Komitmen\%20dan\%20Kepuasan\%20Kerja\%20thd\%20OCB .pdf, diakses 10 Februari 2017)

Yoon, Mahn. Hee, Suh, Jaebeom. 2003. Organizational citizenship behaviors and service quality as external effectiveness of contact employees, Journal of Business Research 56 (2003) 597- 611 